\title{
Canada's air transportation policy case study: The greater Moncton international airport
}

\author{
Valerie Roy, Ec.D.
}

\begin{abstract}
Airports are a major economic engine for the region that it serves. In today's fast paced global economy, easy access to world markets is crucial to companies seeking to expand and take full advantage of business opportunities. This paper will explore how changes to Transport Canada's air policy, from divestiture in 1994 to proposed amendments to the National Airports Policy in 2003, have impacted the Greater Moncton International Airport. An analysis of the policy reveals that while the devolution of Canada's national airport system to local control has been a success, the proposed amendments will negatively affect the way the Greater Moncton Airport Authority serves the public, airport users and, most importantly, the local community.
\end{abstract}

Keywords: Greater Moncton International Airport, divestiture, airport policy

\section{Canada's air policy}

Canada's aviation industry, including airlines, airports and other facets are important to all parts of the country. Other sectors such as tourism are also vitally dependent on air transportation. Business and the public use air travel and air cargo as key parts of their activities. The aviation industry is governed by air policy established by the federal government. The senior level of government has the responsibility for air policy and through that instrument has the means of determining how this vital part of our economy and our society will perform. Government policy in respect to open skies, domestic air service and competition has been equally important.

In economic development terms, an airport is a major economic engine for the region that it serves. In today's fast paced global economy, easy access to world markets is crucial to companies seeking to expand and take full advantage of business opportunities. Airports with adequate passenger and cargo airline services facilitate that accessibility.

In this paper I will explore how changes to Transport Canada's air policy, from divestiture in 1994 to proposed amendments to the National Airports Policy in 2003, have impacted the Greater Moncton International Airport. 


\section{The national airports system}

The National Airports System (NAS) comprises 26 airports in provincial capitals and major centres across Canada. Together, NAS airports handle 95 per cent of passenger and 98 per cent of cargo traffic in Canada. The National Airports Policy of 1994 established the framework for providing greater local control of NAS airports to local Airport Authorities.

In 1994, a new National Airports Policy called for the commercialization of federally operated airports. Under the policy, the management and development of the 26 National Airports System airports would be transferred to local Canadian Airport Authorities, who would operate under a ground-lease arrangement. That is, they would lease the land and the buildings but own the chattels. Conversely, very small airports were given to the communities in which they were located lock, stock and barrel.

While no longer operating these NAS airports, Transport Canada would continue to provide safety and security through aviation regulation and airport certification.

With 726 airports in the country, 150 of which were operated or subsidized by Transport Canada, the unofficial objective of the exercise was to save government money. Officially, the purpose of creating locally based airport authorities was to allow communities to take greater control of their airports, reduce costs, attract new and different types of businesses, improve airport facilities and enhance air services to their communities. In other words to provide airports that were 'safe, commercially viable and cost effective'. Certainly, the expectations of these communities were that their airports were to become economic generators for their regions. However, the initial reality for the majority of these newly created airport authorities was that they assumed control of old infrastructures and large operating deficits.

\section{Divestiture to greater Moncton}

In New Brunswick, there were seven airports at the time of divestiture. Moncton, Saint John and Fredericton airports were owned and operated by Transport Canada. The Moncton airport was one of the first to consider establishing a local airport authority.

In 1988, when the Mulroney government first announced its intention to transfer federally run airports to local authorities, the Transportation Committee of the Greater Moncton Chamber of Commerce established a task force to investigate the process. There was a firm belief that the Moncton airport would drive future economic development within the region. Greater Moncton, as the geographic centre of the Maritimes, had a long history as the transportation and distribution hub for both road and rail. However, with the closing of the CN shops in 1988 and 
the loss of over 2,000 well-paying jobs, the region's importance as a railway hub was clearly in decline and the development of the airport became even more crucial.

Due to its location at the geographic centre of the Maritimes, the Moncton airport had the potential to develop as 'the' airport of the region. Within a two-hour catchment area (customers within a two-hour drive) the airport had 1.2 million potential customers. The Halifax International Airport had just 650,000 within a two-hour catchment area. The Chamber's task force was disbanded however, when eight months later, Transport Canada decided to start the transfer process with Canada's Tier 1 airports. Tier 1 airports are classified as those having 1 million or more passengers annually. Montreal, Calgary, Edmonton and Vancouver were quickly transferred and became profitable under local management.

When the 1994 Transportation Act took force, allowing for the transfer of Tier II airports (airports having 200,000 passengers or more annually, or that are provincial capitals), it was clear that Transport Canada did not have a vision for the Moncton area. During the 1970s, Transport Canada and Air Canada had invested heavily into the Halifax airport. Moncton was not considered a hub and was therefore relegated to feeder status when it came to capital investments. It was therefore imperative that the community get control of the airport, otherwise it would simply continue to provide feeder service to Halifax or at worse, the airport would go into decline and eventually fail.

The Chamber's Transportation Committee reinstated the Airport Task Force, which was responsible for setting up the parameters for the Airport Transfer Committee. Bill Whalen, CEO of the Greater Moncton Chamber of Commerce during the initial period of investigation in 1989, was elected chair of the transfer committee with the mandate to begin the negotiations. At that time, \$250, 000 in seed money was obtained from the National Bank with a note signed by Dieppe, Moncton and Riverview - the three municipalities served by the airport.

The airport authority also received support from Frank McKenna, then Premier of the province. He understood the importance of the Moncton airport to the region and the province as a whole. In his view, Saint John had its port; Fredericton was a capital city and university town; Moncton was the transportation hub of the province. With a much larger catchment area than Halifax Airport, Moncton Airport's potential was unrivalled in the province of New Brunswick.

Due to the work done in the late 1980s, there was a lot of basic understanding of the transfer process. However, there was no real blueprint and the Greater Moncton Airport Authority was often very frustrated in its dealings with Transport Canada. Again, because of the latter's investments into Halifax Airport, it was felt that Transport Canada did not 'give a damn' about Moncton. 
The deal that was on the table did not seem fair. It included the reconstruction of runway 06/24, the purchase of the rolling stock (e.g. snow plows), as well as other equipment that, for a price of $\$ 2,181,855$, which was considered highly overvalued. The terminal building, which was built in 1953 , was too small and too expensive to operate $(\$ 202,000$ per year in utilities alone) and subject to code violations that would have to be addressed immediately upon transfer. However, despite these discouraging facts, the community felt it was important to get off the mark first and take advantage of an estimated one-year window of opportunity.

When the airport transfer was completed on September 1, 1997, the Airport Authority was faced with a deal that imposed many challenges. Among others, it had inherited a $\$ 2$ million per year operating deficit, which immediately created an unfair playing field between it (GMAA) and its counterparts throughout Atlantic Canada. As predicted, one month after the transfer of the airport to local authority, a number of agencies sent their inspectors to the Moncton Airport and several code violations were cited. Plumbing, electrical and construction codes were out of date. It was estimated that the cost to bring the terminal building up to code or to complete major renovations would be in excess of $\$ 2$ million.

While Transport Canada provided the GMAA with $\$ 5.8$ million at time of transfer ( $\$ 1$ Million for Operations and Maintenance, \$2.4 Million for capital equipment and \$2.0 million towards a $\$ 6.8$ million runway project), the latter was tied to a time frame of two years. Runway 06/24, sometimes known as the bad weather runway, needed to be rebuilt. The cost was estimated at $\$ 6.8$ million. This meant that in order to access the $\$ 2$ million from Transport Canada, the GMAA would be obliged to borrow the remainder, adding another $\$ 4.8$ million to its debt. In addition, by 2005, \$2.1 Million would be owing for chattels.

The transfer team understood that if the runway work could not be completed, the airport would have to degrade to one runway, eliminate its passenger services and stick to cargo. This would fit well with Transport Canada's plan to have Moncton become a cargo hub within the National Airports System. However, that would also mean that the Moncton Airport would remain a Tier II airport and never have the opportunity to grow to Tier I status (over 1 million passengers a year). In addition, as a cargo hub, Moncton would not pose a threat to Halifax. The reconstruction work had to be completed by December 1999 - which meant just a little more than two years from the date of transfer to go through all of the project management steps, secure bridge financing, tendering, technical and geological work that the project would require.

Once again however, the three municipalities came through for the GMAA. The Authority secured $\$ 4.8$ million in funding from the Royal Bank, which was guaranteed by the municipalities of Moncton, Dieppe and Riverview. 
Runway 06/24 was completed on time and on budget, and included a new apron which became part of the project when Moncton hosted le Sommet de la Francophonie - an international event that required the capacity to land large jets. Despite this success, the federal government did not seem willing to renegotiate the transfer deal, which by all accounts, was one of the worst deals given to any airport in the country.

An article in the Times and Transcript outlined just how unfair that deal has been to the Greater Moncton Airport. The article "Deal restricts airport potential" states that the transfer agreement "saddled the facility with a $\$ 2$ million deficit creating an unfair playing field between it (GMA) and its counterparts throughout Atlantic Canada." In fact, an October 2000 report by Auditor General, Denis Desautels, confirmed that Moncton got a raw deal in the transfer. In the report, the Auditor General criticized Transport Canada's 'ad hoc' approach to airport privatization across the nation, which led to a lack of fairness. "The Department could not demonstrate how the deals for all the transferred airports were equitable, uniform, consistent and fair with the other, as the government has directed" Mr. Desautels stated in a news release. (Source: Office of the Auditor General of Canada and the Commissioner of the Environment and Sustainable Development News release October 17, 2000).

In the report he also stated that Transport Canada 'lacked rigour' for having no idea of the fair market value of the airport businesses before it negotiated the transfers. Transport Canada invested \$5.5 million in the Moncton airport in 1997, compared to \$9.2 million in Saint John in 1999 and close to \$17 million in Fredericton - \$12 million more than Moncton received in 1997. Perhaps the most difficult aspect for the region to absorb was that these subsequent deals provided unrestricted monies to local authorities up front, allowing them to earn interest on these funds while infrastructure improvements were being made.

Other inhibiting factors presented by the Moncton deal included aspects of the land lease arrangement with Transport Canada. Again, the airport authority owns the chattels of the airport (snowplows, trucks etc.) but does not own the land or buildings, effectively making them the guardians of public property. The land-lease arrangement is for 60 years with a 20-year option. In addition, the airport authority has to provide NavCan, Customs \& Excise and military vehicles with free rent and services.

In June 2001, Transport Canada Minister David Collenette was reported to say that the Moncton transfer agreement 'deserved a second look.' Although he disagreed with the methodology used by the Auditor General, he did send officials to Moncton to review the deal. However, despite solid arguments from local officials, the federal government has not reopened the deal - even though they promised to do so if it was discovered that the original deal was flawed. 
Despite these restrictions, since taking over control of the airport in 1997, the Greater Moncton Airport Authority has been able to effectively eliminate the $\$ 2$ million per year operating deficit (a modest profit was recorded in 2000), passenger traffic increased from 240,000 in 1997 to a projected 450,000 in 2003 , and it has attracted new airlines and new services to the facility.

\section{Domestic air policy}

Although Atlantic Canada has only seven per cent of Canada's population, it has 25 per cent of Canada's NAS airports. This is a direct result of our lower populations and even lower percentages of urban-based populations than in other regions of Canada.

Current government policies dealing with the restructuring of Canada's airline industry have resulted in problems for most of these airports. Air Canada has enjoyed considerable influence with Transport Canada regarding aviation policy and airports. Since the divestiture of airports, Air Canada has worked hard to maintain its level of influence over divested airports. Recent events, facilitated by the Federal Government, have given Air Canada a monopoly status in most airports in Atlantic Canada.

Monopoly power extends to a significant ability to affect the future economic development prospects of a community. For example, the acquisition of Canadian Airlines by Air Canada resulted in significant route consolidations, the loss of 40 per cent of daily scheduled passenger flights and approximately $\$ 600,000$ in revenue at the Moncton airport. Under current regulations, it can be very difficult for a new entrant to compete directly with Air Canada in the market. As well, current regulations place restrictions on U.S. based carriers that preclude them from serving our domestic routes, unless they have a code share agreement with Air Canada, limiting their trans-border opportunities. However, Air Canada, which has approximately 80 per cent of the market, is being closely watched by the Competition Bureau - which is anxious to see airline competition in Atlantic Canada.

The competition legislation, which was assented on June 29, 2000, gives the Commissioner of Competition a new power to make temporary orders halting anti-competitive acts affecting domestic airline services. Due to the dominance of Air Canada in the domestic market, there has been a concern about the ability of consumers to obtain a fair price - especially in more isolated areas where the routes might be considered less than competitive.

In November 2001, the Bureau came close to shutting down Tango, Air Canada's low cost carrier - but Canada 3000 collapsed. Tango was the coup de grace for Canada 3000, which had earlier bought out CanJet; the no-frills airline established to link Atlantic cities with central Canada. WestJet Airlines also claims to be the target of a number of initiatives by Air Canada to stifle growth and disrupt its success, with the goal to further its dominance of the Canadian airline 
industry. It also claims that Air Canada's predatory pricing tactics are responsible for putting six Canadian airlines out of business. When Air Canada was given approval to acquire Canadian Airlines, the government amended federal anti-competitive legislation intending to stop Air Canada from driving competition out of the market.

In order to have effective and efficient airline service at a reasonable cost, Transport Canada must create a competitive market for air carriers. This involves reducing barriers to entry into the Canadian airline market place. It is incumbent on the federal government to encourage and promote an environment that fosters competition in the airline industry on an international, transborder, national and regional basis.

In Atlantic Canada, competitive air carriers are required to help resolve the air access issues and assist in reducing the financial burdens placed on airports. New discount carriers and regional U.S. carriers offer the best potential for alternate service in Atlantic Canada. However, to attract either of these options, regulatory change is required.

In addition to protection against predatory activity, there must be changes to invite and nurture competition by U.S. carriers. Cabotage rights in Atlantic Canada would allow them to carry passengers point-to-point, as well as transborder. This would allow regional U.S. carriers that are interlined with major U.S. carriers to offer service that would carry passengers from their Canadian point of origin to a U.S. destination on one ticket. This would allow U.S. carriers to achieve reasonable loads and offer effective pricing.

In the June 2001, Canada Transportation Act review, the review panel provided a list of recommendations in its final report Vision and Balance. In the section, The Airline Industry, recommendation 7.1 stated that "the panel recommends the government enter into negotiations with the United States and Mexico to create a North American Common Aviation Area in which carriers from Canada, U.S. and Mexico would compete freely." Minister Collenette must bring this item to the forefront and show leadership in this debate (www.reviewctaexamenltc.gc.ca/english/pages/ctar-recommendations.htm).

The Atlantic Provinces Chamber of Commerce (APCC) has long been a supporter of open skies over North America. The fears expressed by the Minister of Transport, and rhetoric about the number of American airlines that began flying into the regions and subsequently pulled out are not reasons to move away from open skies but conversely, are reasons to negotiate a more open agreement over the continent. 'The fear that our country's airline industry would suffer from such a move is unfounded', contests the APCC. Canadian airlines have been profitable in the past, even though they have been restricted in routes and serve a relatively small population base. 
New England and Atlantic Canada have a history of working together that predates the American Revolution and this relationship grows annually as we strive to make the Atlantic Northeast a strong region. However, it is not uncommon to hear participants in many of the cross border conferences complain 'you can't get there from here!' There is a need for an airline that would serve the communities in the Atlantic Provinces and New England and with reciprocal cabotage, a strong business case could be made for such an airline.

Despite widespread consultation with stakeholders and plans by the federal government to announce further constructive air policy changes, these have not emerged. The anticipated new phase of Open Skies with the United States has not been realized. With the emergence of a dominant national carrier, the aftermath of September 11 and the interruption in global economic growth, the need to revisit and improve Canada's air policy is clear.

\section{Airport security and the air travellers security charge}

When the federal government announced in the 2001 budget that it would take responsibility for improved airport security, it was evident that it wanted to provide Canadians with assurances that their airports and airplanes would be secure. Over $\$ 2.2$ billion was allotted for air security initiatives and a new Canadian Air Transport Security Authority (CATSA) was created. The CATSA would be responsible for the provision of key air security services: pre-boarding screening at Canadian airports, deployment of explosive detection equipment; certain airport policing services and contracting for armed police on board aircraft.

Other initiatives included providing funding to airlines to help cover costs of security modifications to existing aircraft, resulting from new standards and regulations, and hiring new inspectors to provide increased oversight of aviation security. However, there was nothing in the announcement by the federal government to cover the airport operator's costs associated with these new or enhanced security measures. For example, the GMAA was required to hire nine new security commissioners, but there was no funding provided to cover salaries for these individuals.

The Air Travellers Security Charge that was implemented on April 1, 2002 was considered excessive and there appeared to be no link between the fee that air passengers were paying and the amount of security that would be provided. The Air Travellers Security Charge was also imposed without Transport Canada having conducted any impact analysis on how this change would affect the airlines, the travelling public, business travel, the communities and other stakeholders.

The Canadian Chamber of Commerce examined the cost side of providing airport security across Canada and concluded that required spending in 2002-2003 on airport security would be 
approximately $\$ 223$ million, far less than the $\$ 430$ million dollars budgeted revenue from collecting the charge. (Air Travellers Security Charge. Page 135 Canadian Chamber of Commerce Policy Positions 2001-2002). Moreover, the federal government budgeted one billion dollars over the next five years for the purchase, deployment and operation of advanced explosive detection systems at airports across the country.

Security equipment in airports belongs to the Airline Transportation Security Commission, which is in turn paid for by air carriers. However, airports are required to provide space and security for the machines, adding extra costs to already strained bottom lines. In the opinion of the manager of the Moncton Airport "airports are not considered an integral partner in the airline industry as far as security goes." Clearly, as key stakeholders, airports should have been part of the consultation process.

In 2002, the Canadian Chamber of Commerce made a number of recommendations to the federal government including the linking of the Air Travellers Security Charge paid by passengers to the level of airport security that is received. They also recommended that the Air Travellers Security Charge be set at a level that will provide the required level of security in the long-term but will have the least effect on the overall demand for air travel and minimize the impact on smaller communities.

On February 28, 2003 John Manley, Deputy Prime Minister and Minister of Finance, announced that the Air Travellers Security Charge would be reduced by more than 40 per cent for air travel in Canada as of March 1, 2003. The rate would be reduced to $\$ 7$ from $\$ 12$ for one-way travel and to $\$ 14$ from $\$ 24$ for return flights in Canada for tickets purchased on or after March 1, 2003, for flights on or after that date. Tickets purchased before March 1 would be subject to the previous rate regardless of when the flight is taken. The $\$ 12$ rate for travel to the continental United States and the \$24 rate for other international travel would remain unchanged. While this announcement followed up on the Government's commitment to review the Air Travellers Security Charge to ensure revenue remains in line with the overall cost of the enhanced air travel security system, once again consideration was not given to the realities that smaller airports face nor any differences from region to region.

\section{Capital investments and safety concerns}

Canada's air transportation system depends heavily on capital investments to maintain safety and efficiency. The airport authorities that manage National System airports are fully responsible for capital improvements to their airports. However, they do not qualify to receive public funding for capital improvements. Pre-devolution, Transport Canada was paying \$135 million annually to support the airports system. By 2001 it was collecting over \$245 million each year in 'rent' from 
airport authorities. Although Transport Canada has divested itself of most of its financial obligations to small airports, it still has the authority to impose regulations concerning safety.

While there is little doubt that safety is a principal concern of a viable transportation system, many of these regulations have significant cost impacts that smaller airports may not have the means to meet. For example, the mandatory nature of Canadian Airport Regulation 308 Aircraft Emergency Intervention Services poses large cost burdens on small airports and may leave them with little scope to pursue other important upgrades such as runway resurfacing and lighting. Newly and unsupported regulations such as CAR308 are being imposed without acceptable risk analysis and will further jeopardize the future of smaller airports.

In a presentation to the Atlantic Canada Liberal Caucus on May 1, 2003, the Atlantic Canada Airports Association expressed concerns that over the next several years, the NAS airports will continue to pay rent to the federal government that will inflate to half a billion dollars per year, while the effect of the federal government's historical investment in airport infrastructure will continue to decline. This has important implications for the air transportation system and must be addressed by the federal government.

\section{Bill C-26 and Bill C-27}

Bill C-26 enactment amends certain statutes in order to implement specific elements of the Policy Framework for Airline Restructuring in Canada of October 26, 1999 and to make a consequential amendment. The key elements of the enactment include amendments to the Canada Transportation Act authorizing the Governor in Council to approve mergers and acquisitions of airline undertakings after review by the Minister of Transport, the Commissioner of Competition and the Canadian Transportation Agency; increased authority for the Agency to review passenger fares and cargo rates on monopoly routes; authority for the Agency to review domestic terms and conditions of carriage; the requirement for notice of exit in cases of major passenger seating capacity reductions resulting from discontinuance of services on any domestic route; a prohibition of exclusive use clauses in confidential contracts for domestic services.

In May 2003, the Canadian Chamber of Commerce (CCC) submitted its views in response to Bill C-26 to the House of Commons Standing Committee on Transport. Page 2, paragraph 3 of their presentation points out that the current National Transportation Policy indicates that "competition and market forces are, whenever possible, the prime agents in providing viable and effective transportation services." Further, the National Transportation Policy also states that "economic regulation of carriers and modes of transportation occurs only in respect of those services and regions where regulation is necessary". 
Following on this policy, the federal government's transportation blueprint entitled 'Straight Ahead-A Vision for Transportation in Canada' advocates less regulation and government intervention. They concurred that some of the benefits of deregulation and competition have included increased air passenger and air cargo traffic with the U.S. resulting from the liberalization of air traffic with the U.S and increased private investment in critical transportation infrastructure including, among others, airports.

However, the Canadian Chamber of Commerce opinioned that implementation of Canada's transportation policy has been ad hoc and inconsistent. In many cases, the implementation of this policy has not supported the NAFTA trade approach and has not recognized Canada's transportation capacity as an integrated part of a North American economy. As a result, the full benefits of a competitive market-based system have yet to be realized, and barriers to growth and profitability remain. In conclusion, they submitted that the proposed amendments, intended to further regulate the domestic air travel industry, will have a negative impact on the domestic airline industry and do not address the critical issues currently facing the industry, such as unfair taxation.

Bill C-27, the proposed Canada Airports Act, which received its first reading in the House of Commons on March 20th, 2003, will address new and emerging issues as the roles and responsibilities of airport authorities are more clearly defined. In addition, a National Airports System (NAS) rent policy review will assess the fairness of the current rent policy and its impact on the air transportation system. These changes will ensure the efficient and effective operation of Canada's NAS airports and will result in a more open and transparent system.

As previously stated, the Greater Moncton Airport Authority (GMAA) currently lives and operates under a ground lease that was negotiated with Transport Canada in 1997. The ground lease is approximately eight inches thick and contains sufficient flexibility to operate the airport in a commercial manner. The 1994 National Airports Policy that guided the airport transfers had a basic premise "local operation and commercialization of the airports will promote costefficiency and the provision of services matched to user needs." However, Bill C-27 severely tightens up numerous areas of the ground leases, which in turn severely hampers an airport's ability to act in a business or commercial like fashion.

In the opinion of the GMAA, this Act is so prescriptive in nature and so fraught with bureaucratic red tape, particularly when it comes to achieving financial self-sustainability, it will kill any incentive Airport Authorities might have to develop their airports into economic generators for their communities. For example, section 6 (3) of the Act Airport Fees requires that airport operators who wish to establish or raise a fee must a) explain how the fee is set and describe the purpose for which the revenues from the fees are to be used; b) provide opportunities for users and other parties to obtain information about the proposal and express 
their views about it; c) announce its decision in respect of the proposal after considering the views of the users and other parties.

Users and other parties would include the airlines, passengers and members of the community at large. Such a process would be onerous, expensive and time consuming. As a result, many airports may simply choose stagnation rather than growth. There is also the danger that competition will be stymied through this Act. In addition to regulating the establishment or increasing of fees, section 6 establishes charging principles that would disallow differentiation of fees among air carriers on the basis of their nationality. This means that airports could not use fee differentiation as a method to provide incentives to attract foreign carriers. In fact, it could be argued that, because of this Act, airports will now have to perform as extensions of Transport Canada's bureaucracy with little or no incentive to be creative or entrepreneurial; much like the days when Transport Canada ran them. As well, the associated costs to do everything required in this Act would be significant for small to medium sized airports.

The Atlantic Canada Airports Association sees the Canada Airports Act as a broad-brush attempt by the federal government to re-regulate airport administration and management. New levels of red tape will force airports to devote more resources to compliance rather than focusing on viability and economic stimulation. In letters to Minister Collenette and Joe Comuzzi, MP, Chair of the Standing Committee on Transport, the Greater Moncton Chamber of Commerce expressed its concerns about the impact that this legislation on the GMAA's ability to respond to local needs and the circumstances of our region. The Chamber requested that committee members visit the region to see for themselves how much the airport means to local businesses and citizens. As well, it requested that the GMAA have the opportunity to appear before the committee to present its perspective on the Act and its potential negative impact on the region's economic development.

\section{Summary and conclusions}

The devolution of Canada's NAS airports to local control has been a success. The transfers were negotiated in good faith with local community-based authorities. Transfers have been successful because the community is involved and empowered. Airports have been operated in a businesslike manner and have become instruments for economic development.

The March 12, 2002 strategic economic development plan for the Greater Moncton region presented by Grant Thornton to Moncton City Council identified continued development of the Greater Moncton International Airport as the "single most important piece of the economic development plan for the Greater Moncton area." In addition to direct economic generators such as the development of passenger facilities, an Aerospace Park and cargo handling facilities, the 
airport will facilitate other economic generators including increased investment from the USA and further development of the tourism sector (Infrastructure, Pg. 5).

In retrospect, 2002 was a tough year overall for anyone in the aviation industry and it was difficult for airlines and airports alike to justify service expansions. However, that being said, the Greater Moncton Airport Authority has established aggressive management objectives for 2003 including identifying new business opportunities, attracting third-party developers to construct a common use cargo facility and attracting continental USA transborder services. As well, a number of important capital expenditures have been identified for the next five years, including the extension of runway $06 / 24$, as this is of particular importance to the expansion of cargo/courier services.

To assist the GMAA in achieving these goals and objectives, the federal government should be required to review the transfer agreement and ensure that the region's funding is "equitable, uniform, consistent and fair with the others, as the government has directed." Further, changes should be made to current regulations to ensure that there is competition in the airline industry. Competition will encourage new entrants to the market, resolve air access issues, reduce fares, increase the numbers of passengers and overall, reduce the financial burdens placed on airports.

While the federal government must have the overall responsibility for safety issues, it should, however, be required to consult with all stakeholders, including airport authorities, on all policies that modify existing standards or impose new regulations - especially where there is a financial impact to the operator. One recommendation from the ACAA is that the Canada Airport Act exclude costly compliance for all airports with less than 1 million passengers. Another suggests that the federal government should fully-fund all additional policing and security imposed by new regulations.

However, of all these measures, it seems clear that, if passed, Bill C-27: an Act to amend the Canada Transportation Act, will have the most profound impact on the way the Greater Moncton Airport Authority serves the public, airport users and, most importantly, our local community.

- There are 40 sections where the Minister can impose regulations;

- There are fundamental changes in the governance rules that give the Minister of Transport more unilateral control;

- The proposed Act seeks to regulate commercial relationship between the airport authorities and their clients;

- Administrative, legal and accounting costs will escalate (perhaps beyond the means of smaller airports). 
The National Airports Policy declaration, item 7 on page 8 of Bill C-27 removes all reference to commercialization and instead declares that "it is in the public interest that there be a national network of airports that are operated in a manner that is safe, secure, economically sustainable, transparent and environmentally responsible." This is a fundamental change from the original NAP principles of commercialization and economic development.

Many communities, including Greater Moncton, are asking why the government is introducing this legislation at this time. Since this Act was first conceived and the first draft tabled, many new variables have impacted the air transportation industry; the war with Iraq, SARS, higher fuel prices and airline casualties around the world, among others. Now is not the time to impose more bureaucracy and red tape. It is time to look at the bigger picture.

It is time to look at measures that will enhance rather than hurt the industry and allow the Greater Moncton Airport Authority realize its full potential as "the air transportation hub of Atlantic Canada for cargo, passengers, and industry, delivering, in partnership with the community, service excellence to all users".

\section{Author Biography}

Valerie Roy was born and educated in Southampton, England. At the age of 18, she emmigrated to Canada and since that time, has lived and worked in Nova Scotia, Quebec and various regions within New Brunswick.

Valerie has more than 30 years experience in both the public and private sectors. As administrative manager with Office Concepts Ltd., she was transferred from Bathurst to Moncton in 1983 when the firm moved its head office. Then from 1989 to 1990, Valerie served as coordinator of Moncton's centennial. During the 1990s, Valerie was an active employee of the Greater Moncton Economic Commission, counselling hundreds of clients from start up through expansion. She also participated on many boards and committees at the local, regional, national and international levels*.

Her position as director, economic development ended on May 16, 2000 when Valerie accepted the position of chief executive officer at the Greater Moncton Chamber of Commerce. In this new capacity, and as a member of the board of Enterprise Greater Moncton, she looks forward to many more years of service to the business community in the Greater Moncton region. 


\section{References}

Atlantic Canada Airports Association. (2003, May 1). A Brief on the Canada Airports Act, A presentation to the Atlantic Liberal Caucus by the Atlantic Canada Airports Association.

Beddoe, Clive. (2002, September 1). Open letter from Clive Beddoe, Executive Chairman, President and CEO, WestJet Airlines Ltd..

Canada Transportation Act. (2001, June). Canada Transportation Act Review. www.reviewcta-examenltc.gc.ca/english/pages/ctar-recommendations.htm

Canadian Chamber of Commerce, The. (2003, May 9). Canadian Chamber of Commerce submission to the House of Commons Standing Committee on Transport. The Canadian Chamber of Commerce response to Bill C-26.

Canadian Chamber of Commerce, The. (2001). Air Travellers Security Charge, Canadian Chamber of Commerce Policy Positions, 2001-2002.

Government of Canada. (2000, July 5). House of Commons of Canada Bill C-26. Canada Transportation Act, Competition Act, Competition Tribunal Act and Air Canada Public Participation Act and to amend another Act in consequence, An Act to amend the Canada Transportation Act.

Government of Canada. (2003). House of Commons of Canada Bill C-27. An Act respecting airport authorities and other airport operators and amending other Acts, First reading March 20, 2003, The National Airports Policy declaration, item 7.

Greater Moncton Airport Authority. (2002, July 15). The Greater Moncton Airport: A Story of Growth, A presentation by the Greater Moncton Airport Authority to the Moncton Rotary Club.

Greater Moncton International Airport. (2003, May 9). The Greater Moncton International Airport 2002 Annual Report. Presented at the Annual General Meeting.

Office of the Auditor General of Canada and the Commissioner of the Environment and Sustainable Development. (2000, October 17). www.oag-bvg.gc.ca/domino/media.sf/html

Se donner les ailes: Guide pour les intervenants, November 2000. 
Thornton, Grant. (2002). Taking Charge - A Strategic Economic Development Plan for the Greater Moncton Area.

\section{Acknowledgements}

I would like to thank the following individuals for their participation in a number of interviews that provided the background information required for this paper.

Pierre Michaud, Chairman, Greater Moncton Airport Authority

Rob Robichaud, President and CEO, Greater Moncton Airport Authority

Bill Whalen, President, Corporate Communications Limited, Moncton 